\title{
Hubungan Performa Kerja Petani Dengan Produktivitas Padi di Desa Sidosari Kecamatan Natar Kabupaten Lampung Selatan
}

\author{
Relationship of Farmers Work Performance with Rice Productivity in Sidosari \\ Village, Natar Sub-District, South Lampung District
}

\author{
Oleh: \\ Surya Fajar ${ }^{*}$, Tubagus Hasanuddin ${ }^{2 *}$, Indah Listiana ${ }^{3 *}$ \\ ${ }^{1}$ Jurusan Agribisnis, Fakultas Pertanian, Universitas Lampung. \\ ${ }^{2}$ Program Studi Penyuluhan Pertanian, Fakultas Pertanian, Universitas Lampung. \\ Jl. Sumantri Brojonegoro 1, Bandar Lampung, 35145, Lampung, Indonesia \\ "email: surya_fr@ymail.com
}

Received: April 24, 2021; Revised: June 17, 2021; Accepted June 30, 2021

\begin{abstract}
ABSTRAK
Penelitian ini bertujuan untuk mengetahui hubungan performa kerja petani dan produktivitas masyarakat petani di Kecamatan Natar Kabupaten Lampung Selatan. Penelitian ini dilakukan di Desa Sidosari Kecamatan Natar Kabupaten Lampung Selatan pada bulan Oktober 2020 sampai Januari 2021. Dua puluh petani sebagai responden dipilih dengan metode Accidental sampling. Metode analisis yang digunakan dalam penelitian ini adalah metode analisis deskriptif kuantitatif, sedangkan pengujian hipotesis dilakukan menggunakan uji statistik non parametrik korelasi Rank Spearman. Hasil penelitian menunjukkan bahwa Terdapat hubungan yang nyata antara performa kerja dengan produktivitas pada masyarakat petani di Desa Sidosari Kecamatan Natar Kabupaten Lampung Selatan dengan nilai koefisien korelasi $0,503^{*}$, memiliki tingkat korelasi yang kuat dengan arah hubungan positif dan signifikan. Jika performa kerja petani meningkat maka produktivitas masyarakat petani padi di Desa Sidosari Kecamatan Natar Kabupaten Lampung Selatan juga meningkat.
\end{abstract}

Kata kunci: petani, performa kerja petani, produktivitas

\begin{abstract}
This study aims to determine the relationship between farmer work performance and productivity of farmer communities in Natar District, South Lampung Regency. This research was conducted in Sidosari Village, Natar District, South Lampung Regency from October 2020 to January 2021. Twenty farmers as respondents were selected by using Accidental sampling method. The method of analysis used in this research is quantitative descriptive analysis method, while the hypothesis testing is done using the nonparametric statistical test of correlation Rank Spearman. The results showed that there is a significant relationship between work performance and productivity in the farming community in Sidosari Village, Natar District, South Lampung Regency with a correlation coefficient value of $0.503^{*}$, which indicates a strong correlation level with a positive and significant relationship. When the farmer's work performance increases, the productivity of the rice farming community in Sidosari Village, Natar District, South Lampung Regency will also increase.
\end{abstract}

Keywords: farmer, farmer work performance, productivity 


\section{PENDAHULUAN}

Sektor pertanian merupakan salah satu sektor yang berperan penting dalam meningkatkan perekonomian di Indonesia. Andajani (2010) dalam penelitiannya menyebutkan bahwa sektor pertanian memiliki peranan penting bagi perekonomian di Indonesia yaitu sebagai pemasok bahan pangan dan bahan baku industri, sumber pendapatan nasional, menyediakan kesempatan kerja, sumber investasi, serta penghasil devisa negara.

Berdasarkan BPS (2017) jumlah tenaga kerja di Kabupaten Lampung Selatan menempati peringkat ke-3 dengan jumlah pada sektor pertanian yaitu 191.292 jiwa, atau sebesar 10,78\%. Sektor pertanian di Kabupaten Lampung Selatan memberikan sumbangan yang cukup besar dibandingkan dengan sektor lainnya dalam hal penyediaan lapangan kerja terutama di daerah pedesaan. Oleh karena itu pertanian sangatlah berperan penting dalam mata pencaharian masyarakat petani untuk pembangunan pertanian. Namun, Dalam usaha tani, produk yang dihasilkan akan baik jika faktor-faktor produksi telah dimanfaatkan secara efektif dan efesien sehingga produksi yang dihasilkan akan meningkat yang membuat produktivitas juga meningkat.

Berdasarkan BPS (2019) produktivitas padi tertinggi di provinsi Lampung terdapat di Kabupaten Lampung Selatan yakni sebesar 60,33 kwintal per hektar. Hal ini menunjukkan bahwa lahan pertanian di Kabupaten Lampung Selatan dikelola secara maksimal sehingga menghasilkan produktivitas yang tinggi dan dapat berpengaruh terhadap performa kerja para petani padi.

Menurut data BPS (2019), Kecamatan Natar mengalami penurunan produksi padi dari tahun 2017 hingga tahun 2018 sebesar 1.187 ton pada padi sawah dan pada padi ladang sebesar 1.663 ton. Kemungkinan hal ini disebabkan oleh penurunan performa pertanian atau kinerja petani dari awal proses penanaman sampai panen. (Rahim, 2007) mengatakan luas lahan merupakan faktor kunci dalam usaha pertanian. Semakin luas lahan (yang digarap/ditanami), semakin besar jumlah yang dihasilkan oleh lahan tersebut. Sehingga luas lahan sangat berpengaruh terhadap produktivitas. Semakin banyak produksi yang dihasilkan maka semakin besar pula pendapatan yang diperoleh petani.

Hasil penelitian Hasanuddin, Viantimala \& Fitriyani (2019) menyebutkan bahwa kinerja PPL dan kepuasan petani terhadap PPL berhubungan nyata dengan produktivitas usahatani dan pendapatan usahatani yang diperoleh petani. Sehingga menurunnya performa kerja petani di sektor pertanian juga berpengaruh terhadap penurunan produktivitas petani, hal ini menyebabkan pendapatan yang diperoleh petani menjadi tidak menentu sebagaimana hasil penelitian Achtin (2011) yang menyebutkan bahwa produktivitas berpengaruh terhadap pendapatan sebesar $99,1 \%$. Pertumbuhan penduduk yang semakin tinggi dan hasil produksi padi yang tidak menentu juga menjadi masalah yang dihadapi petani.

Berdasarkan uraian diatas, maka tujuan dari penelitian ini adalah mengetahui hubungan performa kerja petani dengan produktivitas masyarakat petani pada sektor pertanian di Kecamatan Natar Kabupaten Lampung Selatan.

\section{METODE PENELITIAN}

Penelitian ini dilakukan di Desa Sidosari Kecamatan Natar Kabupaten Lampung Selatan. Desa Sidosari merupakan salah satu Desa yang terdapat di Kecamatan Natar Lampung Selatan. Berdasarkan monografi di Desa Sidosari Kecamatan Natar termasuk dalam Wilayah Kabupaten Lampung Selatan dengan memiliki luas wilayah 2,97 $\mathrm{km}^{2}$. Penduduk di Desa Sidosari Kecamatan Natar kabupaten lampung selatan berjumlah 4.681 jiwa.

Berdasarkan informasi SIMLUHTAN (2021) terdapat 16 poktan di Desa Sidosari Kecamatan Natar Kabupaten Lampung 
Selatan. Jumlah anggota poktan yang berada di Desa Sidosari yang berjumlah 331 orang dengan jumlah laki-laki sebesar 300 orang dan perempuan sebesar 31 orang. Adapun nama kelompok tani yang terdapat di Desa Sidosari yaitu Karya Mandiri, Karya Manunggal, Anugrah, Sejahtera, Sinar Muda, Tani Maju, Sidosari, Sido Makmur, Bina Mandiri, Subur Tani, Mandiri Jaya, Marga Rukun, Sinar Abadi, Rejo Tani, Jaya Makmur, KWT Mawar.

Mata pencaharian masyarakat Desa Sidosari sebagian besar adalah petani padi. Dengan lokasi yang sangat strategis usaha tani padi menjadi salah satu prioritas masyarakat. Masyarakat Desa Sidosari corak kehidupannya beraneka ragam, baik itu dari segi status ekonomi, sosial budaya, pendidikan maupun pekerjaan. Ada yang menjadi PNS, pedagang, buruh dan sebagainya. Akan tetapi yang berprofesi petani padi juga cukup dominan dibandingkan pekerjaan lainnya, dan tidak sedikit pula yang berprofesi sebagai PNS, pedagang, buruh dan sebagainya yang memiliki usaha tani padi. Biasanya mereka mengerjakan atau merawat padinya sendiri ataupun mempekerjakan buruh untuk merawatnya dan membagi hasilnya saat panen.

Populasi penelitian ini adalah anggota kelompok petani yang berada di Desa Sidosari sebanyak dua puluh enam orang petani. Pengambilan sampel dilakukan dengan teknik Accidental sampling, yaitu teknik penentuan sampel data berdasarkan kebetulan.

Teknik pengumpulan data dapat dilakukan dengan observasi (pengamatan) partisipatif, interview (wawancara), dan dokumentasi (Sugiyono, 2005). Analisis yang digunakan dalam penelitian ini adalah metode analisis deskriptif kuantitatif, sedangkan pengujian hipotesis dilakukan menggunakan uji beda dan statistik non parametrik korelasi Rank Spearman (Siegel, 1997) dengan menggunakan rumus:

$$
r_{s}=\frac{6 \sum_{i=1}^{n} d i^{2}}{N^{3}-N}
$$

Keterangan:

$r_{s}=$ Koefisien korelasi

$d i=$ Selisih antara ranking dari variabel

$\mathrm{n}=$ Jumlah sampel

Rumus $r s$ ini digunakan atas dasar pertimbangan bahwa dalam penelitian ini akan melihat korelasi (keeratan hubungan) antara variabel-variabel dari peringkat dan dibagi dalam klasifikasi tertentu.

\section{HASIL DAN PEMBAHASAN}

\section{Deskripsi Variabel X (Performa Kerja Petani)}

Karakteristik responden merupakan karakter serta nilai-nilai yang berkembang dari seorang individu yang dapat membedakan antara seseorang dengan indivisu lainnya. Peraturan Menteri pertanian Nomor 91 tahun 2013 (dalam Hasanuddin, Viantimala \& Fitriyani, 2019) menjelaskan bahwa untuk menilai kinerja penyuluh pertanian terdapat tiga indikator dalam menilai kinerja tersebut diantaranya, 1) persiapan pelaksanaan penyuluhan pertanian, 2) pelaksanaan penyuluhan pertanian, dan 3) evaluasi pelaporan penyuluhan pertanian. Menurut Sumual, dkk (2015) Indikator yang menghasilkan kinerja yang sangat baik ialah tersusunnya program penyuluhan pertanian sesuai dengan kebutuhan petani, tersusunnya rencana kerja penyuluhan pertanian di wilayah kerja, dan terdsedia informasi teknologi pertanian secara merata. Selanjutnya hasanuddin, Viantimala \& Fitriyani (2019) menyebutkan bahwa ketersediaan sarana dan prasarana untuk mendukung kegiatan penyuluhan pertanian yang dilakukan oleh PPL berhubungan dengan tingkat kinerja PPL tersebut. Pada penelitian kali ini indikatorindikator yang digunakan untuk mengukur tingkat performa kerja antara lain yaitu sarana produksi pertanian, proses produksi pertanian, pemasaran hasil produksi pertanian, keuntungan usahatani, sumber modal, nilai tambah yang diperoleh, hambatan atau kendala dalam bidang 
pertanian, dukungan masyarakat dan dukungan pemerintah terhadap kegiatan di bidang pertanian. Responden dalam penelitian ini adalah masyarakat petani yang ada di Desa Sidosari Kecamatan Natar Kabupaten Lampung Selatan yang berjumlah 20 orang.

\section{Sarana produksi pertanian}

Sarana produksi pertanian adalah segala jenis perlengkapan, peralatan dan fasilitas pertanian yang berfungsi sebagai alat utama dalam pelaksanaan produksi pertanian, terdiri atas bahan-bahan seperti benih, pupuk dan obat-obatan. Menurut Hasanuddin, Viantimala \& Fitriyani (2019), ketersediaan sarana dan fasilitas kerja yang mendukung juga akan berpengaruh terhadap kinerja penyuluh dalam membantu para petani untuk meningkatkan tingkat produksi usahatani yang diperoleh serta pendapatan usahatani dan kesejahteraan mereka.

Sebanyak $45 \%$ petani padi memiliki tingkat sarana produksi pertanian yang sedang. Hal ini menunjukkan bahwa hampir setengah masyarakat petani Desa Sidosari Kecamatan Natar Kabupaten Lampung Selatan sudah memiliki sarana produksi pertanian yang mendukung proses produksi padi. Namun masih banyak juga petani yang belum memiliki sarana produksi pertanian yang lengkap seperti sumber modal. Beberapa petani masih kesulitan memenuhi modal kegiatan pertanian.

\section{Proses produksi pertanian}

Proses produksi pertanian meliputi persemaian benih, pengolahan lahan, penyiangan tanaman dan pengairan yang baik pada tanaman sebagian besar petani padi dengan persentase $55 \%$ memiliki tingkat proses produksi pertanian yang sedang. Hal ini menunjukkan bahwa sebagian besar masyarakat petani Desa Sidosari Kecamatan Natar Kabupaten Lampung Selatan sudah melakukan proses produksi tanaman dengan baik untuk memperoleh hasil panen yang maksimal.
Kemampuan petani dalam mengendalikan organisme pengganggu tanaman penggangu tanaman akan berdampak positif terhadap peningkatan produksi hasil lahan sawah yang dimiliki petani (Listiana, 2017). Namun masih ada beberapa petani yang belum melakukan proses produksi tanaman dengan baik dan benar.

\section{Pemasaran hasil produksi pertanian}

Hasil produksi pertanian dan olahannya membutuhkan perencanaan yang dapat meningkatkan kesejahteraan masyarakat petani. Perencanaan tersebut tidak hanya terkait pada produksi dan produktivitas tanaman saja tetapi juga pada sektor pemasaran hasil pertanian yang mampu memberikan keuntungan bagi masyarakat petani, baik kelompok maupun perseorangan. Pemasaran merupakan tahap yang krusial dalam keseluruhan proses pertanian, sebaik apapun hasil produksi yang diperoleh jika tidak disertai strategi pemasaran yang baik justru akan mendatangkan kerugian.

Pemasaran hasil produksi pertanian meliputi lokasi pemasaran, jaringan pemasaran, harga jual dan waktu pemasaran. Sebesar $45 \%$ petani memiliki tingkat pemasaran hasil produksi pertanian yang sedang. Sebagian besar pemasaran hasil produksi pertanian masyarakat petani Desa Sidosari Kecamatan Natar Kabupaten Lampung Selatan sebagian besar sudah sesuai dengan yang diharapkan.

\section{Keuntungan usahatani}

Keuntungan usahatani diperoleh dari hasil pemasaran yang dikurangi dengan biaya pengeluaran. Sebanyak $45 \%$ petani padi memiliki tingkat keuntungan yang sedang. Secara keseluruhan keuntungan usahatani yang diperoleh masyarakat petani Desa Sidosari Kecamatan Natar Kabupaten Lampung Selatan masih belum merata. Sebanyak $45 \%$ petani masih memiliki keuntungan rendah, hal ini disebabkan oleh beberapa hal seperti hasil produksi yang 
belum sesuai harapan dikarenakan proses produksi yang belum maksimal ataupun harga jual yang belum sesuai dengan harga yang berlaku di pasaran sehingga keuntungan yang diperoleh belum maksimal. Sebagaimana penelitian Hasanuddin, Viantimala \& Fitriyani (2019), berdasarkan hasil penelitian di lapangan diperoleh kenyataan bahwa tingkat pendapatan usahatani sangat dipengaruhi oleh banyak variabel seperti besarnya biaya produksi yang harus dikeluarkan, kualitas produksi yang dihasilkan, dan tingkat harga jual produksi yang diperoleh pada saat panen.

\section{Sumber modal}

Ketersediaan modal yang dimiliki mempengaruhi produksi pertanian dan hasil produksi. Heriani, Zakaria \& Soelaiman (2013) dalam penelitiannya menyebutkan bahwa menurut petani, ketersediaan modal menjadi faktor risiko yang dianggap mempengaruhi petani terhadap usahatani tomat. Apabila modal yang dimiliki petani sedikit, maka kegiatan usahatani tidak berjalan dengan baik. Sebaliknya, jika modal yang dimiliki petani banyak, kemungkinan dianggap tidak ada masalah dengan risiko usahatani tomat. Modal yang banyak akan meminimalisir resiko dalam produksi pertanian. Sebanyak $45 \%$ petani padi di Desa Sidosari Kecamatan Natar Kabupaten Lampung Selatan memiliki tingkat sumber modal yang rendah. Sumber modal yang dimiliki masyarakat petani padi tersebut masih tergolong sedikit. Hal ini dikarenakan sebagian petani tidak memiliki cukup modal sendiri, pinjaman yang diperoleh juga terkadang belum sesuai dengan jumlah yang dibutuhkan dan membutuhkan waktu yang cukup lama.

\section{Nilai tambah}

Produksi pertanian diharapkan mampu memenuhi kebutuhan ekonomi masyarakat petani, baik dalam bentuk peningkatan pendapatan maupun penciptaan lapangan kerja. Hasil yang belum maksimal dari produksi pertanian dapat ditingkatkan dengan mengolah hasil produksi ke dalam bentuk lain sehingga memperoleh harga jual yang lebih tinggi. sebagian petani padi dengan persentase $55 \%$ memiliki tingkat nilai tambah yang sedang. Sebagian besar masyarakat petani sudah memperoleh nilai tambah yang cukup untuk meningkatkan penghasilan. Hal ini dikarenakan hasil dari produksi pertanian dinilai kurang maksimal sehingga rata-rata petani berusaha mendapat penghasilan lebih banyak dengan meningkatkan nilai tambah.

\section{Hambatan atau kendala dalam kegiatan pertanian}

Kendala-kendala yang dihadapi dalam kegiatan pertanian meliputi modal, sarana, proses produksi pertanian, pemasaran, harga yang berlaku di pasaran, dll. Penelitian Daryanto (2012) menyebutkan bahwa risiko atau kendala usahatani terjadi selama proses produksi berlangsung dan risiko terhadap harga jual. Menurut petani terdapat beberapa faktor yang berkaitan dengan risiko, baik faktor eksternal maupun internal. Faktor ekternal ditunjukkan melalui perubahan iklim/cuaca, serangan OPT, harga sarana produksi, harga output, sedangkan faktor internal ditunjukkan melalui ketersediaan modal penguasaan lahan dan kemampuan manajerial. Sebanyak $40 \%$ petani padi di Desa Sidosari Kecamatan Natar Kabupaten Lampung Selatan memiliki tingkat kendala dalam kegiatan pertanian yang sedang. Kendala yang dihadapi petani bermacammacam, dari sumber modal yang terkadang cukup sulit didapatkan, sarana produksi pertanian yang belum lengkap, maupun pemasaran yang biasanya harga jual tidak sesuai dengan yang diharapkan.

\section{Dukungan masyarakat dalam kegiatan pertanian}

Kegiatan pertanian pada dasarnya juga membutuhkan dukungan baik dari pemerintah maupun dari masyarakat sekitar. Dukungan yang dapat diberikan masyarakat terhadap kegiatan di bidang pertanian antara 
lain dukungan modal, ketersediaan sarana, tenaga kerja, kegiatan pemasaran, hingga bantuan pengetahuan informasi terhadap kegiatan di bidang pertanian. Petani padi dengan persentase $50 \%$ memiliki tingkat dukungan masyarakat dalam kegiatan pertanian yang sedang. Dukungan yang diperoleh dari masyarakat membantu masyarakat petani dalam mempengaruhi peningkatan hasil produksi pertanian sehingga berpengaruh juga terhadap peningkatan penghasilan yang diperoleh dari kegiatan pertanian.

\section{Dukungan pemerintah dalam kegiatan pertanian}

Dukungan pemerintah terhadap petani sangat dibutukan terutama dalam hal ketersediaan modal, pemasaran (dapat terjual dengan harga yang layak), jaminan terhadap harga pasar hasil usahatani, dan ketersediaan sarana prasarana yang menunjang kegiatan pertanian. sebagian petani padi dengan persentase $40 \%$ memiliki tingkat dukungan pemerintah dalam kegiatan pertanian yang tinggi. Sebagian besar masyarakat petani sudah memperoleh dukungan pemerintah. Dukungan yang diperoleh dari pemerintah sangat membantu masyarakat petani padi dalam meningkatkan hasil produksi pertanian sehingga berpengaruh terhadap peningkatan penghasilan yang diperoleh dari kegiatan pertanian.

\section{Deskripsi Variabel Y (Produktivitas)}

Produktivitas pertanian sangat dipengaruhi oleh input dan output dari pertanian. Input dari pertanian meliputi musim tanam dan lahan pertanian, sedangkan output dari pertanian meliputi hasil pertanian yang dikelola. sebagian besar petani padi dengan persentase 90 persen memiliki tingkat produktivitas yang rendah. Hal ini menunjukkan bahwa Penghasilan yang di dapat dari sektor pertanian tidak menentu dan menunggu hasilnya terlalu lama. Performa pertanian yang belum maksimal mempengaruhi produktivitas yang diperoleh masyarakat petani seperti modal yang dimiliki tidak banyak maka proses produksi pun mengalami kendala karena modal yang terbatas sehingga hasil produksi juga tidak maksimal.

\section{Analisis Hubungan Variabel X dan Y}

Berikut disajikan hasil uji korelasi antara performa kerja dengan produktivitas pada masyarakat petani:

Tabel 1.

Hasil analisis korelasi performa kerja dengan produktivitas masyarakat petani

\begin{tabular}{llcc}
\hline Variabel x & Variabel y & $\begin{array}{c}\text { Koefisien } \\
\left.\text { korelasi ( } \mathrm{r}_{\mathrm{s}}\right)\end{array}$ & $\begin{array}{c}\text { sig. (2- } \\
\text { tailed) }\end{array}$ \\
\hline $\begin{array}{l}\text { Performa } \\
\text { kerja }\end{array}$ & Produktivitas & $0,503^{*}$ & 0,024 \\
\hline $\begin{array}{l}\text { Sumber : Analisis data primer, } 2020 \\
* \text { Correlation is significant at the 0,05 level (2-tailed) }\end{array}$
\end{tabular}

Terdapat hubungan yang nyata antara performa kerja dengan produktivitas pada masyarakat petani. Nilai $0,503 *$ berada pada kriteria 0,51-0,75, berarti tingkat korelasi yang terjadi antara variabel pengetahuan informasi dengan performa kerja adalah kuat. Arah hubungan adalah positif (+) sehingga hubungan kedua variabel searah, artinya jika variabel performa kerja meningkat maka produktivitas masyarakat petani juga meningkat. Sebagaimana hasil penelitian (Roza, Rosnita \& Restuhadi, 2018) yang mengatakan bahwa produksi padi di Kabupaten Siak tidak terlepas dari bagaimana pengaruh kinerja penyuluh pertanian mampu mempengaruhi atau memotivasi petani padi di Kabupaten Siak, sehingga tingkat kinerja penyuluh tersebut mampu mempengaruhi peningkatan terhadap produksi usahatani padi petani. Karena apabila produksi padi petani meningkat maka hal itu menandakan kinerja penyuluh yang sudah baik.

Hal ini dapat diketahui pada masyarakat petani yang memiliki performa kerja lebih tinggi maka hasil produktivitas yang diperoleh dari usahatani lebih sesuai dengan yang diharapkan dengan rata-rata hasil 
produktivitas pada kisaran 4,73 ton/Ha. Dari hasil data jawaban petani diketahui proses produksi cukup sesuai dengan yang diharapkan seperti persemaian benih, pengolahan lahan, tahap pemeliharaan penyiangan, dan tahap pemeliharaan pengairan tanaman sudah dilakukan oleh sebagian besar responden.

Hasil produksi pertanian juga sudah cukup sesuai, seperti jaringan pemasaran yang cukup mudah dipasarkan oleh tiap responden, harga dalam produksi pertanian yang cukup stabil, waktu pemasaran yang cukup mudah, dan keuntungan yang sudah cukup sesuai.

Sumber modal yang masih belum merata mempengaruhi proses produksi sehingga berpengaruh juga terhadap produktivitas yang dihasilkan. Nilai tambah yang diperoleh dalam bidang pertanian sudah cukup tinggi untuk sebagian besar responden, hal ini membantu petani dalam menambah angka keuntungan yang diperoleh. Jangka waktu untuk memperoleh nilai tambah juga sudah cukup tinggi.

Hambatan dan kendala dalam kegiatan di bidang pertanian responden terbilang cukup banyak, seperti pada kegiatan pemasaran, kegiatan hasil produksi, harga yang berlaku di pasaran, pengolahan lahan, proses pemeliharaan atau penyiangan, pengairan, dan permodalan. Sementara kegiatan nilai tambah produksi responden lebih sedikit hambatan.

Dukungan masyarakat ada terhadap responden, seperti kegiatan produksi, tenaga kerja dan pengetahuan informasi. Sementara dukungan untuk modal, pemasaran, dan alat produksi terhadap responden masih sedikit. Dukungan pemerintah cukup banyak terhadap kegiatan permodalan, namun pada kegiatan informasi, benih, pupuk, alat produksi dan pemasaran lebih sedikit dukungan terhadap responden.

\section{SIMPULAN}

Terdapat hubungan yang nyata antara performa kerja dengan produktivitas pada masyarakat petani dengan nilai koefisien korelasi $0,503^{*}$ memiliki tingkat korelasi yang kuat dengan arah hubungan positif dan signifikan. Jika performa kerja petani meningkat maka produktivitas masyarakat petani juga meningkat.

\section{UCAPAN TERIMAKSIH}

Ucapan terimakasih ditujukan kepada pihak-pihak yang membantu, mengarahkan, membimbing dan memberikan masukan dalam pelaksanaan penelitian maupun penyusunan artikel ini.

\section{DAFTAR PUSTAKA}

Andajani, T. K. 2010. Peranan Pertanian dalam Sistem Perekonomian Indonesia (Modul 2). UB Press. Malang.[Diakses Pada Tanggal 7 Juli 2020]

BPS [Badan Pusat Statistik] Provinsi Lampung. 2017. Penduduk yang Bekerja Ketenagakerjaan pertanian Menurut Umur. Bandar Lampung.

BPS [Badan Pusat Statistik] Kabupaten Lampung Selatan. 2017. Lampung dalam Angka 2016. Bandar Lampung.

BPS [Badan Pusat Statistik] Kecamatan Natar. 2018. Natar dalam Angka 2017. Bandar Lampung.

BPS [Badan Pusat Statistik] Provinsi Lampung. 2017. Penduduk yang Bekerja Ketenagakerjaan pertanian Menurut Umur. Bandar Lampung.

Daryanto, A., \& Daryanto, H. K. 2012. Analisis Perilaku dan Strategi Pengelolaan Risiko Petani Cabai Merah pada Lahan Kering Dataran Tinggi di Jawa Tengah. Jurnal Sosio Ekonomika, 15(2).

Dyas Achtin, N. P. 2011. Pengaruh Produktivitas terhadap Kesejahteraan Petani Padi di Kecamatan Gunungpati Kota Semarang. Disertasi. Universitas Negeri Semarang. Semarang.

Hasanuddin, T., Viantimala, B., \& Fitriyani, A. 2019. Kinerja Penyuluh Pertanian Lapangan, Kepuasan Petani, dan 
Produktivitas Usahatani jagung di Kecamatan Natar, Kabupaten Lampung Selatan. Suluh Pembangunan : Journal of Ekstension and Development, 1(2), 134-141.

Heriani, N., Zakaria, W. A., \& Soelaiman, A. 2013. Analisis Keuntungan dan Risiko Usahatani Tomat di Kecamatan Sumberejo Kabupaten Tanggamus. Jurnal Ilmu Ilmu Agribisnis : Journal of agribussines Science, 1(2).

Listiana, I. (2017). Kapasitas Petani Dalam Penerapan Teknologi Pengendalian Hama Terpadu (Pht) Padi Sawah Di Kelurahan Situgede Kota Bogor. Jurnal Agricia Ektensia, 11(1), 46.

Roza, Rosnita, \& Rosnita. 2018. FaktorFaktor yang Mempengaruhi Kinerja Penyuluh Pertanian Dan Dampaknya Terhadap Produksi Padi Petani Di Kabupaten Siak. Pekbis Jurnal, 10(1), 1-11.
Siegel, S. 1997. Statistik Non-Parametrik Ilтu-ilmu Sosial. PT Gramedia. Pustaka Utama. Jakarta.

SIMLUHTAN [Sistem Informasi Manajemen Penyuluh Pertanian]. 2021.

Sugiyono. 2005. Metode Penelitian Pendidikan Pendekatan Kuantitatif, Kualitatif, dan $R \& D$. Alfabeta. Bandung.

Sumual, N. S., Benu, O. L., Kapantow, G., \& Tarore, M. L. 2015. Kajian Kinerja Penyuluh Pertanian di Wilayah Kerja Balai Penyuluh Pertanian, Perikanan dan Kehutanan (BP3K) Kecamatan Amurang Timur. COCOS, 6(2). 